\title{
Sébastien Gadal
}

\section{SOME FUNDAMENTALS OF THE FRENCH POLICY IN THE ARCTIC}

\begin{abstract}
Despise a long tradition of research in the Arctic region, French policy in the Arctic in appearance seems to be running backwards. President of the French Republic François Hollande presented France's roadmap during the Arctic Circle in November 2015 in Reykjavik with the main objective being to increase the French Arctic presence in the political, diplomatic and scientific arenas. The formalised Arctic policy is based on four aspects with the environmental issue in the background: political, scientific, economic and environmental. The policy of France in the Arctic is integrated into those of its allies such as the German Federal Republic and the European Union with numerous close synergies. The sciences are one major key-dimension of French diplomacy in the Arctic. Refs 22.

Keywords: Arctic, French policy, environment, sciences, cooperation.
\end{abstract}

The French policy in the Arctic was characterised by apparent contradictions and by the seeming absence of a tangible policy until the presentation of the French Arctic roadmap policy at the Arctic Circle in Reykjavik in Iceland on the $16^{\text {th }}$ October 2015 by his Excellence François Hollande, the President of the French Republic. Officially presented the 14 May 2016 by Michel Rocard, the French strategic policy is currently under implementation and constitutes one of the bases of the Conference of United Nations on the Climate 21 (COP 21) of December 2015 in Paris. French Arctic policy is partially driven by the COP 21 and the Grenelle 1's French environmental law [1]. French policy in the Arctic lags behind other countries such as Germany, the USA, Poland and Canada. This constitutes an advantage for France because it allows her to take into account the policies developed by other States in conforming to the synthesis policy defined with the European Union, by the United States and the European partners as Norway and Germany. The delay in elaborating a tangible Arctic French policy is hindersome because, despite awareness and interest since the end of 2000's France, in comparison to Germany, seems invisible despite a long and permanent history of scientific activity in the Arctic, economic interests related to oil, gas and natural resource exploitation, fisheries, and political developments since March 2009 with the nomination of an Ambassador for the Arctic, Mr Michel Rocard, a former French Prime Minister.

\section{Fundamentals of the French policy in the Arctic}

\subsection{Sustainable development and environment}

French policy on the Arctic was defined by the European Union: policy focused on global warming regulations, environmental issues, sustainable development of territories and populations, sustainable exploitation of natural resources and regional cooperation. The main initial idea was to combine the exploitation of the natural resources with the protection of the environment, the protection of native populations with sustainable development. Despite Norwegian opposition to Michel Rocard's proposals, this policy has

Sébastien Gadal - PhD, Habilitation, Aix-Marseille Université (AMU) - CNRS ESPACE UMR 7300, Technopôle de lenvironnement Arbois - Méditerranée BP 80-13545 Aix-en-Provence Cedex; sebastien. gadal@univ-amu.fr

(c) Санкт-Петербургский государственный университет, 2016 
been promoted by the Norwegian government [3]. Exploitation of natural resource as off-shore gas and oil can be combined with high-tech technologies, protection of the environment and sustainable development of local populations. The common approach between French policy and the European Union can be explained by the political achievements of Michel Rocard, as deputy member of the European parliament, who defined the EU Arctic policy of 2008 [2], and is representing French interests in the Arctic as Ambassador. Since the end of 2015, French policy has been advocating non-exploitation of fossil natural resources and the exploration of renewable ones [4].

This pillar of French diplomacy is based on the consideration of the strategic importance of the Arctic in terms of environmental issues in the late 2000s. The nomination of an Ambassador for the Arctic issues with the establishment of a diplomatic team in the Arctic, more focused attention from the Ministry of Foreign Affairs, and diplomats responsible for monitoring Arctic policy in concerned embassies express the growing interest of France on the Arctic region since 2006. France is only third country which has a permanent representative to Greenland, a dependency of the Embassy of France in Denmark. The French Republic is also the only none-Arctic State to have an Ambassador for the Arctic in charge for the negotiations' in Polar Regions: Arctic and Antarctic. Both Polar territories are managed by the same diplomatic unit.

\subsection{Science policy and climate change studies: drivers of French Arctic diplomacy}

The second aspect of French policy in the Arctic concerns the central question of climate change and environmental impacts caused by global warming. This is a central keynote of French diplomacy or of French science-diplomacy.

Global warming and environmental issues in the Arctic are focal points of the United Nations Climate Change Conference 21 (COP 21) held in December 2015 in Paris. Interactions with the proposals of the European Union on the Arctic are evident (cf. 1.1). The synergies with the German policy on the Arctic are strong, especially in the scientific domain. It establishes joint key-points of the French policy in the Arctic. France, Germany, China, the United Kingdom, as non-territorial Arctic States have implemented similar policy approaches with a common tool and objective: science constitutes the diplomatic foundations of their state policies in the Arctic area. All these countries are transferring a part of the scientific and academic competences acquired in Antarctica to the Arctic region: both poles have symmetric deep impacts from global climatic change; the understanding and modelling of the climatic dynamics constitute the priority of France's scientific programmes.

The third base of French policy in Arctic concerns mobilisation of the scientific and academic community working in the Arctic region. The idea is to centralise and structure a large part of the research in geosciences and environmental sciences, in process or under construction by the network of the Chantiers arctiques [5]. This network brings together a large part of the scientists and academics working on questions of the climate change in Arctic and in geophysics [6]. French scientists' and academics' groups are working in more than 20 research programs supported by governmental scientific institutions on permafrost, biodiversity and ecosystem, climate-atmosphere-ice-ocean, geodynamics and natural resources; human impact, governance and geopolitics, arctic societies and knowledge systems, observation and modelling [7]. 


\section{French issues for the Arctic: a strategy under construction}

\subsection{Limited economic interests}

Economic interests in the Arctic constitute the last aspect of French policy. They are not mentioned or little mentioned in French policy reports on the Arctic, though they are predominant in the background. This mainly concerns French multinational companies of the oil and gas, mines, fisheries, navigation and maritime safety sectors [8]. They are few, but very active locally, especially in Norway [9]. Norway is the largest supplier of gas to France, with a market share of $38 \%$ in 2012. In terms of oil, Norway is France's fifthlargest supplier [10]. Total, EDF (Engie) and Statoil exploit conjointly the Blanche-Neige gas field in the Barents Sea. France is the second largest importer of Norwegian fish and seafood after Russia in 2013. Salmon is the most consumed fish in France, and $70 \%$ of the salmon consumed therein are Norwegian [10].

The potential opportunities of the exploitation of the natural resources (mines, gas, petrol, fishes, etc.) should be abandoned from the announcement of President François Hollande's proposal [4]. The political inflection of French policy concerning the exploitation of the natural resources can be interpreted as a message to the economic interests of the Russian Federation in the particular context of the tensions with the conflict in Ukraine, in addition of the American and European sanctions. The same day of the discourse of the French Président François Hollande at the Arctic Circle of Reykjavik in Iceland on the $16^{\text {th }}$ of October 2015, the President of United States Barak Obama announced the end of the oil exploration of US companies in the Arctic. There was also a message related to the preparation of the COP 21 Conference in Paris on December 2015.

Of course, the impact of the French position concerning Russian and Norwegian interests cannot be ignored. The Arctic is one of the major economic development issues of development for the Russian Federation - economic, human and territorial, but the dependence on Western technologies and investments is high in the gas and the petrol field. In regard of the sanctions for petrol, US and European major-players have stopped their investments and off-shore exploration in the Russian Arctic. Results of off-shore oil explorations are too little; the great majority of oil and gas reserves are concentrated in the continental zone of the Russian Arctic territory. The off-shore exploitation of the oil and gas in the Arctic sea is merely hypothetical under a price of oil per barrel from $\$ 80.00$ to 100.00 US, and the potential risks of exploitation, incidents, accidents, and impacts on the environment are high. Total decided to stop investments in Arctic oil exploitation in 2012, and then in the Russian Barents Sea (Shtokman project). In Russian extraction, exposure to hard environmental conditions concerns $25 \%$ of the off-shore platform extraction costs in the Arctic.

This political posture is possible because of the small number of French companies active in the Arctic (Total in Norway and Russia with gas exploitation, Areva in Canada with uranium mines), and the separation of interests between the companies, for example, as Total with the French State to the apposition of the British or Russian oil and gas companies. Economic and political interactions are strong. The British government is supporting British Petroleum actively, incestuous links characterise the relationship between Russian oil and gas companies with the Russian Federal State as economic, politic and diplomatic tools. Russia gets $30 \%$ of the production from BP (which owns $20 \%$ of Rosneft), $10 \%$ from Total, $5 \%$ from Shell, and $5.5 \%$ from ExxonMobil. French economic interests 
are limited in the Arctic, located mostly in Norway, partially in Russia and Canada; costs of exploitation are important, success of implementation of this regulation is little according to the strong economic interests for Russia, Greenland (Denmark), Canada and Norway. In addition, in opposition to the hypotheses of the USGS report in 2008 (10\% of World oil reserves and almost $30 \%$ gas estimated by the USGS) [11], the estimated reserves of petroleum are from 8 to $10 \%$ of the Global production at the best, with a drop in production of gas of $22 \%$ from 2050 according of the Norwegian Statistic and the Centre for International Climate and Environmental Research [12].

Ice-melt allows for considering the development of otherwise impossible economic activities with an increase in temperature estimated by the Intergovernmental Panel on the Climate Change (IPCC) of from 4 to 5 degrees by 2050 [11]. It provides access to subsurface resources and sea, opening summer waterways, tourism development, and especially the gas and oil [11], the exploitation of minerals with new deposits: zinc, iron, copper, lead, nickel, tin, platinum, gold, diamonds, uranium, rare earths. Canada has become the third largest producer of diamonds in less than 10 years. Greenland could conceal between $12 \%$ and $25 \%$ of rare earths in the World, valuable to the economy of new technologies and a resource on which China has a near monopoly exploitation.

The opening of new shipping routes in the Arctic Ocean is more complicated: the complexity of the geography and the lack of information make it difficult to open the Northwest Passage by Canada [13]. The summer northern passage by Russia requires very large infrastructure investments. China with direct investment or by the project of the Russian-Chinese bank of development is starting to contribute in the Russian and SubRussian Arctic regions on the building and renovation of transportation infrastructure. It should be noted that Mr. Michel Rocard proposed to create an Arctic Bank of Development first. Today, despise the high need of investments, only the Russian Federation can propose the full umbrella of infrastructure and equipment for the summer opening of the maritime passage. The development of the new generation of ice-breakers, the recent growing of military presence and the building of new bases can be significant for the sensitive navigation's problematic of safety and research and rescue.

\section{2. Scientific and environmental issues}

The policy of France is centred on two aspects: environmental protection and scientific expertise. The French presence in the Arctic is low because the territory is under the sovereignty of the United States, Canada, Iceland, Norway, Sweden, Finland and the Russian Federation. The French implantation is carried out through the establishment of international conventions such as the Svalbard archipelago with two scientific centres, Charles Rabot and Jean Corbel (Treaty of Paris in 1920).

The framework defined by the Grenelle 1's French law of the environment integrates the Arctic issues [14]. One of the objectives is "to support, within the relevant international institutions, the adaptation of international regulations to new Arctic Ocean uses made possible by the increasing accessibility" and "exchange of resources and knowledge, to be justified, as our main partners [...] as a natural extension of successful cooperation in Antarctica" [15]. Research is seen as the element shared by all global institutional and NGO actors, who will make "the right decisions in the region, through a better understanding of its changes" [15]. Research and scientific expertise are also key-elements for participation in 
the Arctic Council. They allow a State Observer such as France to provide Member States with supplementary scientific expertise and requests of the State members of the Arctic Council. It is through science and knowledge that we can analyse the Arctic transformation from a global perspective and remind the challenge of preserving the environment through sustainable development. The ambitions of the French research in the Arctic are limited by the weak budgetary resources. But the logistics deployed are important and increasing with the support of the Institute Polaire Français Paul-Emile Victor (IPEV) supporting each year around 65 research projects [16]. Expertise on two poles is the strength of French research with active scientific networks. China and Germany are following the same policy.

\subsection{Geopolitical interests in the Arctic: climate change and global security}

France, the United Kingdom, and Germany have long conducted scientific activities in the Arctic; China is the most recent major scientific actor since 1980 [17]. But the strategic interests of these non-territorial arctic states are different. French policy in the Arctic constitutes a part of a French Global policy [18]. To be a driver of influence covers the energetic interests of the British government [18]; the priority of Germany is to promote the sciences and develop emerging technologies [19]; the access of natural resources and navigation is an important issue for the Republic of China [17]; financial crises and the EU and US sanctions provide a window of opportunity to expand economic and diplomatic Arctic interests into Scandinavia and Russia.

Four aspects structure the French roadmap in the Arctic: global warming policy, active science diplomacy among different groups of the Arctic Council and organisations of regulation, ecologic and scientific with the project of Arctic as a Global Scientific Interest Zone. The question of maritime security and safety is important with the idea of implementation of high environmental norms including the interdiction of specific transportations in ice-zones - the Arctic sea region becoming a pilot zone for the new marine environmental norms. The last aspect of the French policy concerns the non-exploitation of the oil and gas in the Arctic, and natural resources.

French interests in the Arctic are related to scientific and environmental assets and large networks. There are also economic interests with the support of French companies in the Arctic, the safety and the protection of French and its enterprises. The geopolitical interest is high. "Enfin, en tant que membre du Conseil de sécurité des Nations unies, de l'OTAN et de l'Union européenne, la France serait nécessairement impliquée en cas de crise dans l'océan Arctique, ce qui justifie son intérêt pour l'avenir de cette région”. "“Finally, as a member of the United Nations Security Council, NATO and the European Union, France would necessarily be involved in a crisis in the Arctic Ocean, which justifies its interest in the future of this region".] [1]. The geopolitical and diplomatic position of France is de facto close to the Chinese notion of a "near-Arctic" country.

\section{Synergies}

\subsection{Implementation in European Union Politics}

The Arctic policy of the European Union has been driven by the French geopolitical vision of the Arctic region which combines French and Norwegian economic, environ- 
mental and development issues. Yet this is also incorporated into the problematic of understanding, modelling and simulation of the global dynamics of climate change in the Arctic and in Antarctica. One of the problematic issues in background concerns the capacities of modelling the potential impacts in France and in Europe. Climatic impacts will drive the present and future investments of the State in the infrastructures and environmental legislation. France, the United Kingdom, and Germany have a close scientific approach in studies of the Arctic region: to improve the scientific knowledge of the Arctic region, in regard to Antarctica concerning research on the global modelling of climate change.

The Arctic is the main political and economic issue related to climate change for Europe: evolution of the Gulf Stream, ice weakening, new fish stock repartitions, loss of species, opening new areas for oil and gas exploration, new maritime transportation routes and threats to populations of the North. The policy of France, in particular for establishing its observer status in the Arctic Council, is (a) to develop the means by which knowledge of the Arctic can be applied to environmental challenges and climate change; (b) to contribute to the economic sustainable development of the region based on the sustainable use of resources and environmental expertise; (c) to intensify the dialogue with countries in the region, indigenous people and other partners (States, administrations and NGO) [20], [21]. Over the last 10 years, the European Union has committed over 200 million euros to research and development programs (100 programs) in the Arctic region (climate change, contaminants and health, infrastructure, environmental technologies, capacity building, mapping, space and land) [22]. Three projects will also continue under the new framework program Horizon 2020: "SIOS-PP", funded to the tune of 4 million euros on observation of Svalbard; "Interact project" with 7.3 million euros to create an international research network with Russia, Canada and the United States; and "ACCESS", with 10.9 million euros, on the economic prospects arising from climate change. Earth observation and remote sensing mapping projects continue to be developed and contribute to the building of the "Shared Environmental Information System" as a part of the Observation Network support for sustainable Arctic. The contribution of France by the European Space Agency (ESA), the major European ESA member, with the joint Earth observation programmes is a key to Earth observation and Arctic space monitoring.

\subsection{USA and Canada}

The links of the European Union and France with Canada and the United States are governed by the declaration on cooperation in the Atlantic Ocean of May 2013 signed as part of the transatlantic initiative for marine research. Scientific cooperation with Russia, despite the Cooperation Agreement on scientific research, remains confined to a technical level. The European Union has invested 8.2 million and 6 million euros for the water distribution in the cities of Arkhangelsk and Murmansk under the framework of the Northern cooperation (water management) and Nuclear Safety and Civil Protection (project on the prevention and response to crises in the Euro-Arctic Council of Barents). However, Canada and the Russian Federation continue to obstruct the entry of the European Union in the Arctic Council. The European Union is the major financial contributor supporting science, economic development by means of three countries are EU members (Denmark, Finland and Sweden). The role of the European Union is limited as a provider of funds: "[...] although it is to provide funds for scientific research but not it is expressed on decisions 
about the Arctic" [15]. The future participation of the European Union as member of the Arctic Council will have an impact on the Arctic policy.

\section{Conclusion}

The French policy in Arctic regions is focusing on the impact of climate change and its potential economic implications: fisheries, fish stocks, mines, natural resource exploitation (gas, oil, mineral ores including rare earth in Greenland with 12 to $25 \%$ of world reserves estimated), building infrastructure (needs of infrastructure are also very important), etc., on Maritime security and opening of new summer maritime routes (by Canada and the Russian Federation) and self-guided geopolitical and defence interests. Economic interests are for the moment limited to Norway, and partially in Russia and in the Canada. Total is the second largest enterprise in Norway after Statoil. If French policy in the Arctic is driven by the scientific interests of climate change and global warming; energy in Norway and Russia, security and defence under the umbrella of NATO and the European Union security agreement constitute the third face. This last aspect is excluded from the prerogatives of the Arctic Council.

The French interests of the Arctic directly concern the national level. A large part of the impact of climate change on the national territory depend on the transformation and evolution of the Arctic and Antarctic climate based on the excellence of the scientific and academic research on this field. Research into climate change and global warming are also concerned with the problematic of sustainable development, protection of the northern populations, environmental protection, partnership and supporting the regional dialogue. The implication of French diplomacy on the secure prevention policy of maritime disasters in the Arctic must be noted. French diplomacy is beginning to develop a strategy for one of the potential geostrategic regions of the 21 st century that must accord with the French global interests. The policy of France is clearly moving on two levels: the European and national. It seeks to develop an integrated approach in opposition to a European policy which is certainly ambitious but scattered without an overall clear geopolitical mapping. It is therefore based on the notion of "conciliation". The European Union focuses on the environmental problematic and the development of transport connections and infrastructure in the region, including new shipping routes. The main question is the position of France in the competition for the control of the Arctic Sea among the Arctic countries. The political status of the Arctic actually depends on the different national legislations of the Arctic States and is characterised by the absence of international regulation. The maritime legislation of 1982 has not been ratified by the United States. The demand of extension of sovereignty up to 200 nautical miles (in accordance with the agreement signed in 2009 for Norway), by the Russian Federation (1 millions square kilometres) is a reaction to the geopolitical tensions in the Arctic. Denmark is reinvesting in defence and security, especially in Greenland. Economic interests are few because the oil and gas reserves are located on the continent. Canadian and Russian policy and territorial claims are driven by internal political questions. Russia has developed a regional approach to the Arctic, Canada has adopted a national view. For the USA, the strategic interest concerns the opening of a trans-arctic maritime route. France, according to the Reykjavik dialogue, defends free maritime access to the Arctic Sea as does the United States. The issue is juridical, economic and territorial. Canada and the Russian Federation are pushing for the inland control of the maritime route by levying taxes. 


\section{References}

1. LOI n $n^{\circ} 2009-967$ du 3 août 2009 de programmation relative à la mise en œuvre du Grenelle de l'environnement (1). 52 p. Legifrance.gouv.fr Le service public de la diffusion du droit. Availabe at: https:// www.legifrance.gouv.fr/affichTexte.do?cidTexte=JORFTEXT000020949548 (accessed 29.12.2015).

2. Résolution du Parlement européen du 9 octobre 2008 sur la gouvernance arctique. Parlement europeen. Available at: http://www.europarl.europa.eu/sides/getDoc.do?pubRef=-//EP//TEXT+TA+P6-TA2008-0474+0+DOC+XML+V0//FR (accessed 20.12.2015).

3. Rolf Einar Fife: Ambassador of Norway in France. Arcticque. Les prioprites de la Norvege dans le Grand Nord. France culture. 05.02.2015. Available at: http://www.franceculture.fr/personne-rolf-einar-fife (accessed 20.12.2015).

4. François Hollande: Président de la République française. Arctic Circle. Reykjavik, Iceland. 16.10. 2015.

5. Rousseau D.-D., Babin M. French Arctic initiatives science plan document. CNRS Publ., 2015. 17 p.

6. Bilan et prospective 2015-2020 du Chantier Arctique français. CNRS, 2015, 92 p. Chantier Arctique français. Available at: http://www.chantier-arctique.fr/fr/uploads/Prospective_fevrier2015.pdf (accessed 21.12.2015).

7. Perrin C., Aïchi L., Giraud E. Rapport d’information sur les conséquences géostratégiques du dérèglement climatique. Sénat, 2015, no. 14.193 p.

8. Ministère des affaires étrangères et du développement international. 2015. France diplomatie. Available at: http://www.diplomatie.gouv.fr/fr/dossiers-pays/norvege/ (accessed 20.12.2015).

9. Fifth assessment report (AR5). Climate change 2014 synthesis report. Summary for policymakers. Intergovernmental panel on climate change. $2014.32 \mathrm{p}$.

10. Ambassade de Norvège en France. Norvège. Le site officiel pour la France. Available at: http://www.norvege.no (accessed 25.12.2015).

11. Stauffer P.H. Circum-Arctic resource appraisal: Estimates of undiscovered oil and gas north of the Arctic Circle. USGS Publ., 2008. 4 p.

12. Lindholta L., Glomsrøda S. The Arctic: No big bonanza for the global petroleum industry. Energy economic, vol. 34, issue 5, September 2012, pp. 1465-1474.

13. Martin Fortier. Excutive director of ArcticNet (université de Laval, Québec). France culture, 29.01.2015.

14. LOI $n^{\circ}$ 2009-967 du 3 août 2009 de programmation relative à la mise en auvre du Grenelle de l'environnement (1). $52 \mathrm{p}$.

15. Gattolin A. Rapport d'information sur les stratégies européennes pour l'Arctique: préoccupations européennes pour un enjeu global. Sénat, 2014, no. 684. 190 p.

16. Institut polaire français. 2015. Available at: http://www.institut-polaire.fr/language/en/ (accessed 25.12.2015).

17. Ambassade de France au Royaume-Uni. Les enjeux de l'Arctique : positions britanniques et françaises. Sciences et Technologies au Royaume-Uni. Londres, no. 59, 32 p.

18. Alexeeva O., Lasserre F. China and the Artic, 2012. Arctic Yearbook 2012. University of Akureyri, p. $80-90$.

19. Beckmeyer Uwe. Parliamentary State Secretary, Federal Ministry for Economic Affairs and Energy; Maritime Coordinator of the Federal Government. Arctic Circle. Reykjavik, Iceland, 16.10. 2015.

20. Canadian International Council. Interests and roles of non-Arctic States in the Arctic. Seminar presented by the National Capital Branch of the Canadian International, Council and the Munk-Gordon Arctic Security Program. Ottawa, October 5, 2011.

21. Council of the European Union. Council conclusions on developing a European Union Policy towards the Arctic Region, Foreign affairs Council meeting. Brussels, May 12, 2014.

22. European commission. Developing a European Union Policy towards the Arctic Region: progress since 2008 and next steps. Joint Staff Working Document, Space and the Arctic. Brussels, June 26, 2012.

For citation: Gadal S. Some fundamentals of the French policy in the Arctic. Vestnik of Saint Petersburg University. Ser. 6. Political science. International relations, 2016, issue 2, pp. 110-117. DOI: 10.21638/11701/ spbu06.2016.210

Статья поступила в редакцию 24 декабря 2015 г., рекомендована в печать 10 марта 2016 г. 